\title{
Chapter 13 \\ Social Frontiers: Estimating the Spatial Boundaries Between Residential Groups and Their Impacts on Crime
}

\author{
Ivana Křížková, Meng Le Zhang, Dan Olner, and Gwilym Pryce
}

\begin{abstract}
In this chapter, we highlight the importance of social frontiers - sharp spatial divisions in the residential make-up of adjacent communities-as a potentially important form of segregation. The handful of studies estimating the impacts of social frontiers have been based in the USA and the UK, both of which are free-market democracies with a long history of immigration, ethnic mix and segregation. There are currently no studies of social frontiers in former socialist countries, for example, or in countries where immigration and ethnic mix are only a recent phenomenon or non-existent. This chapter aims to address this research gap by estimating the impacts of social frontiers on crime rates in a post-socialist country, Czechia. We demonstrate how a Bayesian spatial conditional autoregressive estimation can be used to detect social frontiers in this setting, and we use a fixed effect quasi-Poisson model to investigate the impact on crime. Our results suggest that in new immigration destinations, social frontiers may not be associated with higher rates of crime, at least in the short run. Moreover, our use of cultural distance measures helps to promote a more nuanced approach to studying the impact of segregation and highlights the role of cultural diversity in understanding the link between immigrant segregation and crime. We reflect on how this approach could contribute to the study of segregation and inequality in the Chinese context.
\end{abstract}

Keywords Segregation $\cdot$ Crime $\cdot$ Social frontiers $\cdot$ Immigration $\cdot$ Ethnicity $\cdot$ Post-socialist $\cdot$ Bayesian Conditional Autoregressive Estimation

\section{Kř́ǐzová (凶)}

Department of Social Geography and Regional Development, Charles University, Prague, Czechia e-mail: ivana.krizkova@ natur.cuni.cz

\section{Le Zhang · D. Olner · G. Pryce}

Sheffield Methods Institute, University of Sheffield, 219 Portobello, Sheffield, UK

e-mail: meng_le.zhang@ @heffield.ac.uk

D. Olner

e-mail: d.olner@sheffield.ac.uk

G. Pryce

e-mail: g.pryce@sheffield.ac.uk 


\subsection{Introduction}

In countries with a long history of immigration, the issue of segregation, defined as the degree of spatial separation between different groups, ${ }^{1}$ has been a longstanding topic of research and debate among academics, policymakers and the general public. Some view segregation as a symptom of social fragmentation, the inevitable outcome of a flawed vision of multiculturalism (see summary and critique of this perspective in Finney and Simpson 2009; see also Bolt et al. 2008; Phillips 2010). For others, it represents a positive indicator of individual freedom and residential choice (Cheshire 2007), a natural consequence of the human tendency to make friendship connections and find social and emotional support among those most like ourselves (McPherson et al. 2001; Bakens and Pryce 2018). Segregation does not inevitably preclude convivial relations between separate communities (Neal et al. 2013).

Against this backdrop of political discussion and contrasting social visions, a vast and growing academic literature has emerged seeking to quantify the various dimensions of segregation (see Chaps. 2, 4, and 10; Piekut et al. 2019). While huge advances have been made in computing inference for segregation measures (Lee et al. 2015), developing multi-group indicators (Yao et al. 2018: (4) and estimating multi-level measures (Chap. 10; Manley et al. 2018), there are at least four important aspects of segregation that remain under-researched. First, there has been a focus on measuring the overall degree of spatial separation rather than understanding the nature of the interface between different groups (Dean et al. 2018; Legewie 2018). Second, the focus has been on major cities. As a result, we know comparatively little about the nature of segregation in towns and small cities, which are typically neglected in the mainstream segregation literature (Šimon et al. 2021). Third, most publications dealing with segregation come from Western Europe, the US and other established migrant destinations, reflecting the wider Anglo-American hegemony in urban studies and urban geography (Kong and Qian 2017). There are, for example, relatively few robust empirical studies in former socialist countries like Czechia that do not have a long history of immigration, ethnic diversity and segregation. Therefore, there is a need to develop a more rigorous understanding of segregation in regions beyond the usual study areas, where there are nevertheless growing public concerns about these issues (e.g. Dražanová 2018). Fourth, there is a great deal more empirical research estimating the nature and dynamics of segregation than their impacts. As a result, we know relatively little about which types of segregation are problematic, under what circumstances and for whom.

With respect to this fourth point, a notable exception is a work by Maguire et al. (2016: 845) which found that, while the overall level of segregation measured using the dissimilarity index (Massey and Denton 1988; see also Chaps. 2, 4, and 10) had no impact on mental health, the effects of neighbourhood boundaries were very large indeed. Their results indicated that living near 'peacelines' in Belfast-walls erected to keep rival Catholic and Protestant communities apart-increased 'the likelihood of antidepressant medication by $19 \%$ and anxiolytic medication by $39 \%$,

\footnotetext{
${ }^{1}$ E.g. Yao et al. $(2018,1)$.
} 
even after adjustment for gender, age, conurbation, deprivation and crime'. The study by Maguire et al. (2016) reflects a growing awareness in recent years of how important the spatial interface between different groups can be. It is the overall degree of spatial separation that matters and the nature of transitions between residential communities. For example, Dean et al. (2018) have argued that sharp spatial transitions between two groups rather than gradual blending of residents across neighbourhood boundaries may indicate an aversion to living near members of the other group. This, in turn, may be indicative of social tensions and potential conflict. ${ }^{2}$ Dean et al. (2018: 271) coin the term 'social frontiers' to denote these 'places of sharp difference in social/ethnic characteristics between neighbouring communities'. These frontiers can have various consequences, not only on health (Maguire et al. 2016) but also on crime and conflict (Legewie 2018; Legewie and Schaeffer 2016; Dean et al. 2018). In some instances, social frontiers may be places of settled difference where relatively few conflicts occur (Legewie and Schaeffer 2016), while in other cities, they are associated with negative effects for those living in their proximity (Legewie 2018; Dean et al. 2018). Researchers have also explored whether there is a link between social frontiers and xenophobia: Klinger, Müller and Schaeffer (2017) find no significant relationship in Germany where immigration is somewhat more recent.

Perhaps surprisingly, given the vast empirical literature on segregation in Western democracies (Chaps. 2 and 10), research on the impact of social frontiers is relatively recent as the dates of the above studies demonstrate. In Massey and Denton's (1988) much-cited review of segregation analysis, social frontiers are not included in the 'five distinct axes of measurement: evenness, exposure, concentration, centralisation, and clustering'. Two decades later, $\operatorname{Kramer}$ (2017, p. 2), concluded that 'empirical research on neighbourhood boundary making is practically non-existent'. Even now, evidence on the impacts of social frontiers remains limited to a handful of studies, all focused on the US and the UK.

Dean et al. (2018) make the theoretical case for broadening the study of social frontiers. They argue that even if social frontiers do not lead to conflict and crime in the short run, over time, the lack of contact between groups will lead to growing potential for misunderstanding and prejudice (Allport 1954). The absence of 'bridge builders'-residents willing to live on the other side of the social frontier and provide links between otherwise isolated social networks-will limit the capacity of those communities to defuse tensions and prevent incidents escalating into cycles of violence and threat (Dean et al. 2018).

The aim of the current chapter is to help fill some of these gaps in the literature by assessing the impacts of social frontiers on crime rates beyond the usual AngloAmerican locations that dominate the urban geography literature. Our case study area is in a regional capital city in Czechia, a post-socialist country. This provides us with a

\footnotetext{
${ }^{2}$ Researching the impact of differences in land use on crime has a long pedigree. See e.g. Song et al. (2017) for an overview of such studies in criminology, based on which they argue that edges in general may be conducive to crime.
} 
very different socio-historical backdrop for our quantitative study of segregation, and one that might be a more relevant comparator for future research on social frontiers in China.

Our central research questions are: (1) whether social frontiers based on citizenship ${ }^{3}$ exist in Czechia, and (2) whether there is evidence that social frontiers are related to conflicts in a country where immigration is recent? We are also interested in the impact of social frontiers based on more subtle differences in population, which have not been explicitly researched in the quantitative social frontiers literature. Cultural difference is a potentially important factor in determining immigrant integration into the host country: it has proved to be a reliable predictor of conflicts in countries as dissimilar as the former Yugoslavia and India on the regional level (Lim et al. 2007). In order to investigate this, we use the concept of 'cultural distance' between countries. We examine the relationship between social frontiers-defined by the cultural distance of foreign citizens (immigrants) from the non-migrant population-and neighbourhood conflicts. Our two key datasets give exact geolocations for foreign individuals, and for crimes within our study city. These unique sources allow us to investigate these research questions with a level of precision and spatial resolution not usually possible in the segregation research.

Our case study city is Pardubice, located in Czechia, a Central European country with over 40 years of socialist past. Shortly after opening its borders in 1989, Czechia became the main immigration country in the region (Drbohlav and Valenta 2014). As a result, the country's ethnic mix is slowly growing and moving past the socialist aim for homogeneity (Smith 1996). Growing ethnic diversity represents a challenge to the country's national identity and has the potential to carve fault lines in Czech society. Therefore, the specific national context and the country's unique migration system make Czechia an interesting case study that broadens the current knowledge of the impacts of segregation in a previously unexplored setting. Moreover, as the country is the regional leader in the transition from emigration to immigration (Drbohlav 2012), our observations from Czechia might be indicative of future trends in the wider Central and Eastern European (CEE) region.

The remainder of the chapter is structured as follows. The next section discusses in more depth why a post-socialist country should or should not experience the emergence of social frontiers based on ethnicity and why the latter may have effects on residents living in their proximity. In the third section, we introduce our case study area for which we have access to geocoded data on crime and census variables. We describe our methodology for identifying social frontiers and estimating their impact on conflicts. In the fourth section, we present social frontiers based on culturally closer and culturally distant foreign citizens. We report a permutation test results and a quasi-Poisson regression model to assess the link between social frontiers and conflicts in a Czech regional capital city. In the last section, we discuss the implications of our study for policy and further research.

\footnotetext{
${ }^{3}$ Due to the short history of contemporary international migration in Czechia, recent migrants (and the children born to a couple of foreign citizens, the number of which remains limited) might be the only source of non-Czech citizens.
} 


\subsection{Social Frontiers and Their Impact on a Society After Socialism}

In the past CEE socialist countries aimed to achieve an egalitarian society (Smith 1996) through political and economic homogenisation policies including property nationalisation, large-scale housing construction and residential mixing of socioeconomic classes. Despite not fully achieving the goal of equality, socio-economic inequalities within post-socialist societies were smaller than those in capitalist cities (Musil 2005). Due to the very limited potential for crossing national boundaries, international migration was non-existent. Together with the Second World War events, which led to massive population movements in Central and Eastern Europe, this resulted in almost absolute ethnic homogeneity in some socialist countries such as Czechia. ${ }^{4}$

The lack of experience with diversity engendered by international migration is possibly one of the reasons why some CEE populations are among the least tolerant towards immigration in Europe (Čermáková and Leontiyeva 2017). Given the rather hostile approach to difference in these countries, ethnic differences in neighbouring areas might constitute a rift in the social-spatial structures of cities. Following from that, we could assume that the more pronounced the cultural difference between immigrants and the majority population, the stronger the barrier between the two would be. Moreover, social frontiers may emerge from ethnic diversity of population and the dissimilar lifestyles of migrant and majority populations related to their respective cultures and time-space behaviour. Similarly, research in Estonia shows that dissimilar activities of Estonian and Russian speakers in time and space limit encounters between the two groups, which restricts social integration of the two language and ethnic groups (Järv et al. 2015).

However, other characteristics of the post-socialist urban context suggest limited potential for social frontiers' emergence. The most salient reason for this is the current proportion of foreign citizens residing in Central European post-socialist countries. Although their presence is becoming more evident, the limited number of immigrants in CEE countries precludes the emergence of large spatial concentrations of these populations compared with established migration destinations (Drbohlav 2012). An exception to this is workers' dormitories, where immigrants may represent a substantial part of the local population (Přidalová and Hasman 2018). However, these concentrations are usually limited to the level of individual buildings. Moreover, as they are often located near industrial sites, they may be spatially separated from the remaining populated areas, thereby impeding conflicts over territory. In addition to this, the authors are not aware of any evidence of foreign citizens living in deprived areas in post-socialist Central Europe. As most immigration to the area is motivated economically and originates in countries with similar cultures or historical experience of socialism (Eröss and Karácsonyi 2014), the characteristics of immigrants seem to prevent potential conflict with other non-migrants.

\footnotetext{
${ }^{4}$ In contrast, post-Soviet countries like Estonia, Latvia and Lithuania experienced a growth in ethnic heterogeneity due to WW2 and Soviet-induced population movements.
} 


\subsubsection{Social Frontiers in a Post-Socialist Society}

Despite the demographic factors that limit the scale of social frontiers based on country of birth, current political developments in CEE countries suggest that such boundaries may nevertheless emerge as an important issue (Rupnik 2016). The question remains whether social frontiers are associated with problems such as neighbourhood conflict and crime in the nascent phases of immigration in the CEE context. Even if the social frontiers emerge for benign reasons, such as the need for migrants to be located near family and friends for social, linguistic and economic support, over time, the separation implied by social frontiers may cause prejudice and conflict (Allport 1954; Dean et al. 2018). Moreover, several criminological theories provide reasons to expect crime to occur at the borders between sharply dissimilar residential areas.

First, social disorganisation theory holds that residents in transition zones, which are characterised by high residential mobility and ethnic heterogeneity, have fewer networks. This, in turn, weakens social control and increases crime (Sampson and Groves 1989) and can give a cause for concern to neighbouring communities. For instance, the presence of a transient population of students was identified as a factor in weakening social cohesion in post-socialist Budapest (Fabula et al. 2017). Similarly, lesser social cohesion in areas inhabited by a transitory foreign population might produce a greater feeling of insecurity in the neighbouring majority-dominated areas (as shown in Sýkora et al. 2015) and more requests for police activity at community boundaries. This effect may be great in post-socialist countries with rather negative attitudes towards immigrants and a strong tradition of reliance on the power of authorities.

Second, strain theory explains that the discrepancy between expected upward social mobility and the actual possibility of such an achievement may lead to demotivation and in turn to social pathology (Pratt and Cullen 2005). If immigrants work as hard as the remaining population and are less rewarded or do not feel welcome, then spaces of interaction between migrants and non-migrants may become places of conflict. A similar mechanism can also be in place for the native population if its members are less rewarded than migrants. Although we are not aware of evidence of conflicts stemming from the perceived competition limiting the majority or migrant group's social mobility known from countries with a more established history of immigration, signs of concerns in the majority population about competition with migrants on the labour market exist in CEE (Cook et al. 2011; Hlinčíková et al. 2014).

Third, criminological research highlights the role of criminogenic places: locations that offer opportunities that attract or generate criminal behaviour (Brantingham and Brantingham 1995; Haberman and Ratcliffe 2015). For instance, Šimon and Jíchová (2020) observe a stronger concentration of crime in particular places such as commercial and transit locations in inner city and manufacturing and storage areas in the outer parts of a post-socialist regional city. If these opportunities are located close to social frontiers, it is likely that more crime will occur there. 
Nonetheless, social frontiers based on ethnic identity or country of birth need not always be places of heightened social problems. The rational choice model of criminal behaviour posits that an individual commits a crime if the gains from carrying out the crime minus the potential punishment outweigh the gains from legitimate economic activity (Clarke and Felson 1993; Kang 2016). Given the overall attitude towards migration in CEE countries and the likelihood of harsh punishment for potential offenders compared to the relatively attractive pay, immigrants in the CEE region (predominantly labour migrants) are presumably less susceptible to committing crimes. On the other hand, despite unwelcoming political and media discourse about immigrants, the authors are not aware of high profile crimes related to ethnicity being reported in the CEE other than hate speech which, however, tends to be overlooked by authorities (Pejchal 2018). Following this, a general tendency to avoid potential conflicts by immigrants in CEE can be expected. Second, Gould's concept of asymmetric relations states that conflict occurs when several similar-sized groups compete for their respective rank in society (Gould 2003). This is consistent with crime patterns in New York (Legewie and Schaeffer 2016), but the extent of both immigration and conflicts in CEE countries prevents us from testing the same hypothesis empirically. However, the history of contemporary immigration to postsocialist Central Europe is supposedly too short to trigger competition over territory with natives. Third, social problems tend to concentrate in multiply deprived areas. Post-socialist CEE countries inherited a rather egalitarian socio-economic structure where the differences between the majority population and immigrant groups remain limited (Ouředníček 2016). In combination with an urban structure dissimilar from the Western European one (Šimon and Jíchová 2020), it is unlikely that the population of some areas would be comparatively so disadvantaged as to turn to socially pathological behaviour.

\subsection{Methodology}

\subsubsection{Case Study City}

To empirically test the relationship between social frontiers and crime in Czechia, a case study city of Pardubice was selected. The regional capital has a population of around 90 thousand, including some $5 \%$ foreign citizens, ${ }^{5}$ their proportion in the population being slightly above the national average. Two large assembly plants in the city are the main employers of its immigrant population. While migrants are scattered across the city, a few spatial concentrations are stemming from the temporary work agencies' management of migrant workers (Andrijasevic and Sacchetto

\footnotetext{
${ }^{5}$ Given the short history of contemporary international migration in Czechia resulting in a significant overlap of the two groups, the terms 'foreign citizens' (or 'foreigners') can be used as equivalent to 'migrants.' With the exception of Roma population, the number of which is unavailable, immigrants constitute the only significant ethnic minority in the city.
} 


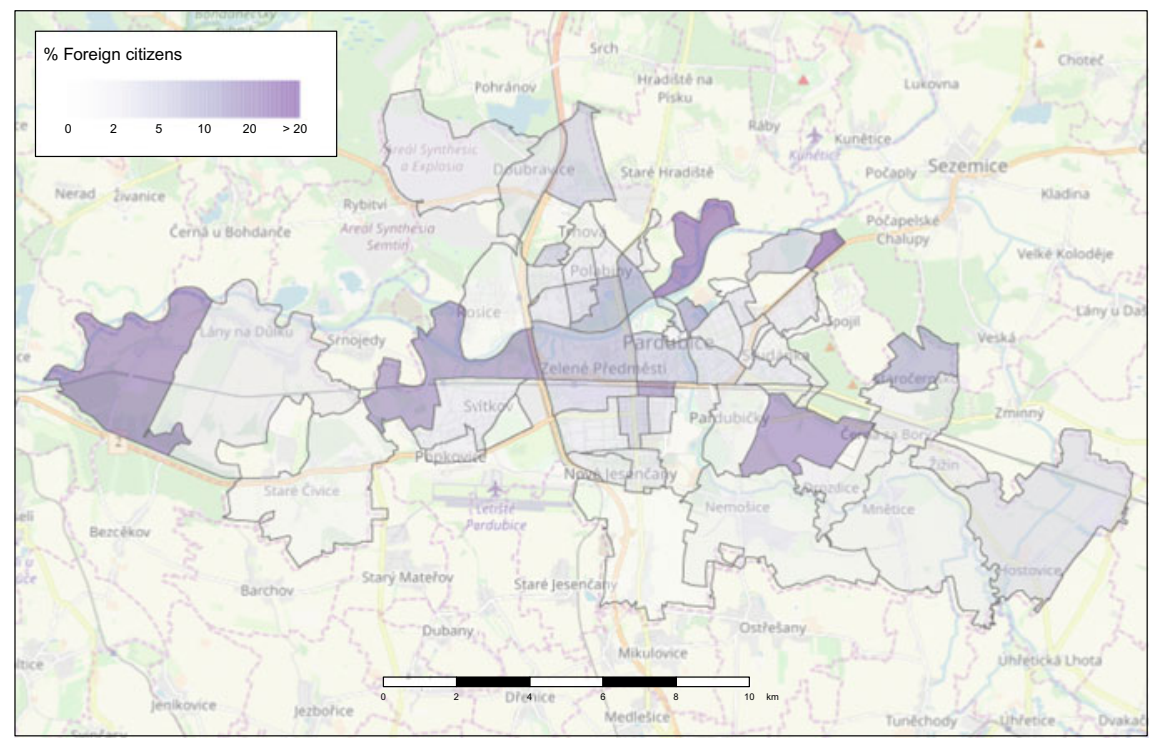

Fig. 13.1 Foreign citizens as percentage of BSU population in 2011. Source: Pardubice: OpenStreetMap contributors, 2017

2008). The most pronounced concentration is the former Soviet army barracks which now serves as cheap workers' accommodation located in the North-East of the city (Fig. 13.1). Previous studies in the city have reported on tensions arising from cultural and language barriers between the majority population and some migrant workers (Sýkora et al. 2015). This might also be partly related to the rather negative media coverage of foreign citizens in the country and the city (Šamánek 2008; Zalabáková 2012).

\subsubsection{Data}

We use two geocoded anonymised datasets made available to the research team. The first dataset includes all foreign citizens registered to reside in Pardubice in 2011. ${ }^{6}$ The database contains around 3,500 individual anonymised records, including information about the individuals' country of citizenship. The largest groups residing in the city according to the database originate from Slovakia (28\%), Ukraine (25\%), Vietnam (15\%) and Mongolia (5\%). The second dataset represents neighbourhood conflict data which contains all $(3,800)$ so-called minor crimes dealt with by the municipal police of Pardubice in 2014. These included minor crimes against public

\footnotetext{
${ }^{6}$ The spatial distribution of foreigners in 2011 is very similar to the one in 2014 , the data for which we could unfortunately not use.
} 
order (67\%, e.g. noise at night, immoral behaviour in public), against property (19\%, e.g. damaging others' property), against civic cohabitation (7\%, e.g. verbal threatening) and others (7\%, e.g. alcohol and drugs abuse). ${ }^{7}$ Although the database includes some details, it does not contain some relevant contextual information about individual conflicts, for example whether they involved ethnic or cultural differences in population, nor does it reveal the ethnic identity of the perpetrator or the victim.

As the datasets are unique and have not been used before, it is important to highlight their limitations. Both sources contain geocoded entities registered with the authorities. The database of foreign citizens includes citizens of countries other than the Czech Republic who hold either a temporary or permanent resident permit. The citizens of EU countries are only required to report to the Czech authorities if their stay in the country is to exceed 30 days. Non-registered foreign citizens such as short-term migrants and undocumented migrants are not taken into account. However, it can be assumed that the spatial distribution of foreign citizens with a temporary or permanent resident permit does not differ significantly from those staying short-term and undocumented ones, as all are dependent on similar infrastructure (Engbersen et al. 2006; Medová and Drbohlav 2013). As we operationalise social frontiers based on the difference in the proportion of foreigners in neighbouring areas, this should not impact our analysis. The conflicts database only provides us with cases where police officers were called to resolve or encountered a minor crime during field work. As with most datasets based on crimes recorded by the police, offences unreported to the authorities thus remain unknown in our data. However, we argue that it is largely the perceived importance of the issue that makes residents report the offences in their neighbourhood. Following from this, despite the likelihood of some underreporting, our data provides a valid picture of neighbourhood conflicts in Pardubice. Despite having these flaws, the geocoded data we employ in this chapter represent the complete sources researchers can use when looking at Czechia. The databases are more detailed and more up-to-date than the traditional data source on foreign population, that is the decennial census.

The variables resulting from the two databases used in the subsequent analyses are the proportion of foreign citizens in the population and the proportion of conflicts per square kilometre, respectively. For further analysis, the individual data were aggregated to 94 Basic Settlement Units (BSU), and the crime data to $100 \mathrm{~m}$ by $100 \mathrm{~m}$ grid squares (the next section explains this in more detail). However, to avoid distortion of the subsequent analyses by outliers and non-residential areas in data, BSUs with less than ten residents were excluded from the analysis. This left us with a final dataset of 61 BSUs.

\footnotetext{
${ }^{7}$ The database which was made publicly available by the municipal police of Pardubice for analytic purposes also includes traffic and parking offenses and administrative records. These were cleared from the database prior to our analyses.
} 


\subsubsection{Methods}

Following Lee and Mitchell (2013) and Dean et al. (2018), we use a Bayesian spatial conditional autoregressive model as a basis for detecting the presence of social frontiers. The aim of the procedure is to detect step changes where the proportion of migrants in a BSU differs significantly from those in an adjacent BSU. The full details of the method can be found in Dean et al. (2018) whose methodology we adapted from English data to our Czech case study.

For each BSU $k$ the total number of foreigners $Y_{k}$ is a function of the total number of residents in that BSU $\left(N_{k}\right)$ and the probability of a resident being a migrant $\left(p_{k}\right)$. The logit transformation of $p_{k}$ is a linear function of an unknown parameter 0 and a random effect $u_{k}$. The random effect $u_{k}$ is assumed to be spatially autocorrelated since the proportion of migrants in a zone $p_{k}$ is likely to be correlated with the proportion of migrants in neighbouring zones due to spatial spillover and shared causal factors. The full Bayesian model is as follows:

$$
\begin{gathered}
Y_{k} \sim \operatorname{Binomial}\left(N_{k}, p_{k}\right) ; k=1, \ldots, n \\
\ln \left(\frac{p_{k}}{1-p_{k}}\right)=\beta_{0}+u_{k} \\
u_{k} \mid u_{-k}, W, \lambda, \tau^{2} \sim N\left(\frac{\sum_{k \sim l} u_{l}}{1-\lambda+\lambda_{w k+}}, \frac{1}{\tau^{2}\left(1-\lambda+\lambda_{w k+}\right.}\right) \\
\beta_{0} \sim N(0, b) \\
\tau^{2} \sim \operatorname{gamma}\left(e^{\prime}, f^{\prime}\right) \\
\operatorname{logit} \sim N(0,100)
\end{gathered}
$$

where $\lambda$ is the parameter affecting how the proportion of foreigners in BSUs surrounding BSU $k$ affects the proportion of foreigners in $k$. $W$ is the $n$ by $n$ spatial weights matrix which determines whether or not the proportion of foreigners in neighbouring zones affects $p_{k}$. In standard spatial models, the matrix $W$ is fixed with values of 0 and 1 , where 1 indicates that two zones are contiguous and 0 otherwise. However, social frontiers occur between geographically contiguous zones that nonetheless have very different proportions of foreigners (i.e. $p_{k}$ ). Following Dean et al. (2018), we allow $W$ to be another set of parameters to be estimated. Starting from the standard spatial weights matrix, we allow values of 1 to be set to 0 . For BSU pairs where this has occurred, this represents a case whereby two contiguous areas have very different proportions of foreigners (i.e. a step change). It is these areas that we identify as social frontiers. 
Three types of social frontiers were identified: (i) foreign citizens as a whole, and for subsets of (ii) culturally closer and (iii) culturally more distant foreigners. Cultural distance between the Czech population and the given group was measured using the World Values Survey, specifically its two-dimensional 'cultural map' where survey data has been reduced to two axes using factor analysis (Welzel 2013). The two axes place countries on a scale between protective versus emancipative values on the one hand and sacred versus secular values on the other. Cultural distance is then simply the Euclidean distance between countries on this graph. To get two groups of culturally closer and more distant countries, all countries are ranked by cultural distance to Czechia and split evenly, so each contains approximately the same number of migrants.

The association between social frontiers and conflicts per square kilometre was tested in two steps. First, this was checked at the administrative level of Basic Settlement Units using 1,000 permutations. Second, a more thorough analysis was performed using a fixed effect quasi-Poisson model. The expected number of crimes $\mu_{i j}$ in a grid square $i$ within BSU $j$ is conditional upon a BSU fixed effect $\delta_{j}$, whether a grid square centroid was within $100 \mathrm{~m}$ of a BSU boundary $x_{i j}$ and whether the centroid was within $100 \mathrm{~m}$ of a social frontier $z_{i j}$. The parameter $\beta_{z}$ indicates the difference in crime counts between grids near BSU boundaries and social frontiers. The inclusion of BSU fixed effect controls for between-BSU differences in factors that might affect crime (e.g. unemployment rates). The quasi-Poisson model includes an additional dispersion parameter to account for the problem of over-dispersion in Poisson models, which can affect standard errors.

$$
\ln \left(\mu_{i j}\right)=\beta_{x} x_{i j}+\beta_{z} z_{i j}+\delta_{j}
$$

\subsection{Results}

\subsubsection{Overview of Social Frontiers}

Despite the rather low overall proportion of foreign-born residents compared to cities in established migrant destination countries, our analysis did identify statistically significant social frontiers based on ethnicity in Pardubice. The overall proportion of foreign citizens in the population is mainly driven by the culturally closer group, which also explains why the social frontiers based on all and culturally closer foreigners are almost identical, being located mostly in the less populated outer parts of the city (Fig. 13.2). On the contrary, there is only one pronounced concentration of culturally more distant foreigners in the above-mentioned BSU with the workers dormitory. Apart from that, the culturally more distant population constitutes a similar proportion of population in most parts of the city. As there are fewer 




Fig. 13.2 Proportion of all (a), culturally closer (b), and culturally more distant (c) foreign citizens in population with the location of social frontiers (red) in 2011

statistically significant and substantially interesting differences between the culturally distant and remaining populations, there are also fewer borders that qualify as social frontiers.

\subsubsection{Social Frontiers and Neighbourhood Conflicts}

Having identified boundaries between areal units which could be called social frontiers, we move on to look at their relationship with conflicts, which we measure using police recorded data on crime. At the administrative level of the BSU, we do not observe any statistically significant relationship between crime levels and the concentration of migrants as a whole, nor for those broken down to culturally closer and more distant groups, and neighbourhood conflict (Table 13.1). However, this analysis uses administrative units of different shapes and sizes, which makes it susceptible to a modifiable areal unit problem (MAUP; Openshaw 1983; see also discussion of MAUP in Chap. 2) and which does not allow us to consider the distance of crimes to the frontiers. Therefore, we next perform a more thorough analysis which 
Table 13.1 The differences in conflicts per sq km between areas adjacent to social frontiers and areas adjacent to borders

\begin{tabular}{l|l|l|l}
\hline & No. of social frontiers & $\begin{array}{l}\text { Mean difference in number of } \\
\text { crime incidents between } \\
\text { frontier-paired and } \\
\text { border-paired BSUs }\end{array}$ & $p$-value \\
\hline All foreigners & 18 & 60.32 & 0.825 \\
\hline Closer cultural groups & 16 & 14.87 & 0.538 \\
\hline More distant cultural groups & 12 & -73.49 & 0.162 \\
\hline
\end{tabular}

looks at conflicts in areas adjacent to the detected frontiers regardless of the shapes of administrative units and consider whether the conflicts occurred within $100 \mathrm{~m}$ of the frontier or not.

The quasi-Poisson model with BSU as a fixed effect gives somewhat different results (Table 13.2). A statistically significant negative relationship was found for grids within $100 \mathrm{~m}$ of frontiers based on all foreigners, suggesting that there is less conflict nearest to the frontiers. This can be explained by the higher proportion of migrants as a whole in peripheral parts of the city where fewer conflicts are reported. Interestingly, another statistically significant relationship we observe is a positive one for more culturally distant migrants within $100 \mathrm{~m}$ of the frontiers. However, fewer of these frontiers and the relationship are likely to be driven by the concentration around the workers' dormitories. Moreover, this relationship may be partly a consequence of some culturally more distant social frontiers detected in the city centre where more conflicts occur in general (Fig. 13.3). This probably derives from the spatial distribution of criminogenic places such as pubs, bars and shops, which predominate in the city centre of Pardubice rather than on the periphery where residential land use prevails.

Table 13.2 Estimations of the effect of proximity to social frontiers on neighbourhood conflicts for all, culturally closer and culturally more distant foreign citizens

\begin{tabular}{l|l|l|l}
\hline & All & Closer & More distant \\
\hline Estimate & $-0.858^{\mathrm{c}}$ & 0.005 & $0.316^{\mathrm{b}}$ \\
\hline S.E & $(0.245)$ & $(0.200)$ & $(0.146)$ \\
\hline Observations & 6,644 & 6,644 & 6,644
\end{tabular}

Notes

${ }^{\mathrm{a}} p<0.1 ;{ }^{\mathrm{b}} p<0.05 ;{ }^{\mathrm{c}} p<0.01$

Dependent variable: total conflicts with a grid within $100 \mathrm{~m}$ of the frontier 


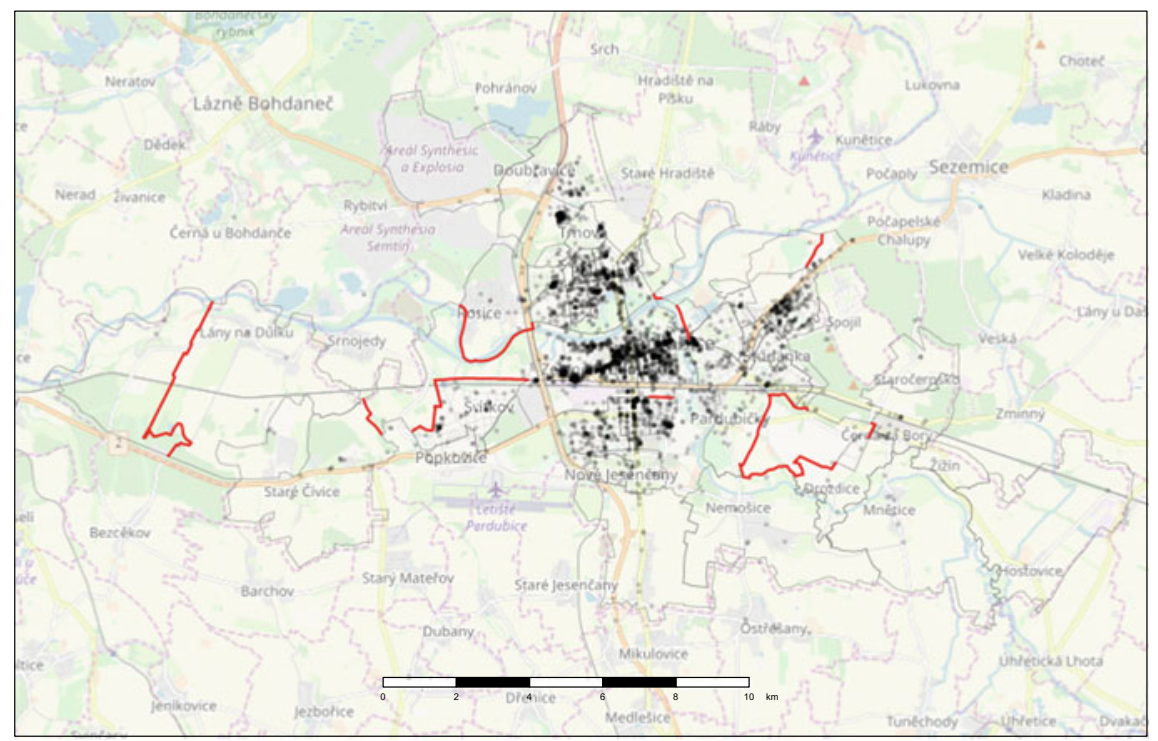

Fig. 13.3 Location of individual conflicts and social frontiers (red) based on all foreign citizens

\subsection{Discussion and Conclusion}

Although our approach successfully identified a number of social frontiers in the Czech city of Pardubice, the evidence for the relationship between these and neighbourhood crime was mixed. We found no significant link between the spatial distribution of foreign citizens in Pardubice and neighbourhood crime at the BSU level. The evidence for grid squares within $100 \mathrm{~m}$ of a social frontier suggests that while frontiers based on the proportion of all foreigners are associated with fewer crimes, the opposite is the case for frontiers based on the proportion of culturally distant foreigners. On the one hand, the statistically insignificant results suggest that social frontiers based on the presence of immigrant population in the Czech context tend to be associated with less conflict or a similar amount to areas not adjacent to social frontiers. This might be due to cultural similarity between migrants and the majority Czech population, which creates less tension between the two groups in spaces where they interact. On the other hand, the positive relationship between culturally distant foreigners and conflicts might be a spurious match between frontier places and existing crime, resulting from immigrant housing and the location of conflicts related to economic opportunity.

Certainly, the estimated impact of social frontiers is much less clear than those observed in established migrant destination countries where similar studies were undertaken. A significant relationship between social frontiers and different types of crime or neighbourhood conflict has been observed in both British and US cities (Dean et al. 2018; Legewie and Schaeffer 2016; Legewie 2018), although to a 
different extent when taking into account the 'fuzziness' of the frontier (Legewie and Schaeffer 2016). On the other hand, no significant link between frontiers and xenophobia was observed in Cologne, Germany (Klinger, Müller, and Schaeffer 2017). These differences may be due to our study's national and local context, where the levels of immigration and crime are lower than in Western Europe and Northern America. In Czechia, migrant communities are less established and their segregation generally only exists at the level of individual buildings. Our results suggest that neighbourhood crime in Pardubice results from an interplay of factors that are considered central by theories that expect an opposing effect of social frontiers on crime, thus pointing to the limited ability of these theories to explain crime in a specific geographic context.

A natural question to ask at this point is why we observe such different social frontier effects in Czechia compared to the UK and the USA? At one level, our results could be interpreted as evidence that social frontiers are not always places of heightened social tensions. The stark contrast between our finding of no clear link between social frontiers and crime, and the positive relationship found in established migration countries (Dean et al. 2018; Legewie 2018), may highlight the importance of cultural and historical background in modifying social frontier effects. This is particularly relevant to the current volume, which seeks to apply insights gleaned from European research on segregation to the Chinese context. History matters for the meaning and consequences of segregation, and that includes social frontiers. Given the very different socio-political history of modern China compared with the traditional study areas for segregation (Chap. 4), we should be cautious about assuming the consequences of segregation will be the same.

One specific aspect of the Czech historical context is the novelty of mass immigration there. It may be, therefore, that social frontiers are unlikely to be associated with higher rates of crime when they arise from migrants self-segregating, not out of antipathy towards the native population, but because of practical necessity-the need for local support networks among extended family and friendship connections.

Crucially, however, we should be careful about drawing long-run or generalised conclusions from our results. Our research on Czechia is based on a snapshot in time. Just because social frontiers appear to have no real impact on crime in the present, it may not remain so. Social frontiers greatly reduce the potential contact between migrant and incumbent communities compared with more mixed residential patterns. The implication of Allport's (1954) contact hypothesis and Dean et al.'s (2018) 'absence of bridge-builders' theory is that this lack of contact could eventually lead to greater distrust, prejudice, misunderstanding and ultimately entrenched division if it is not ameliorated.

One implication for future research on China is the need to find ways not only to explore whether social frontiers have different or similar impacts to the UK and the USA, but whether or not their effects will eventually converge towards those observed in the West. While immigration in China remains negligible, at least relative to the size of the population, Wei Houkai and Su Hongjian have documented in Chap. 5 the huge growth in internal migration from rural to urban areas. This has led to growing residential enclaves of rural migrants (Chaps. 4 and 10), particularly in 
large cities. There is also evidence of ethnic segregation (see Chap. 10) and growing socio-economic segregation following economic liberalisation (Chap. 4). So it will be interesting to see whether the increasing geographical stratification of Chinese society is associated with negative social outcomes such as crime, anxiety or depression, as per that observed in the UK (Dean et al. 2018; Maguire et al. 2016). As with our Czech results, even if we observe no deleterious impacts at first, the wider European and American experience suggests that prolonged spatial separation of social groups, in the long run, can lead to growing tensions and division.

The Czech context also points to the need for further research on the association between the impact of social frontiers and factors related to the actual size, structure and characteristics of the immigrant population, along with those of the host society. The foreign citizen group in Pardubice might not have yet reached the critical mass needed to engender a sense of threat in the host community, triggering competition over territory and social conflict of the kind reported in countries with long-established ethnic minorities (Legewie and Schaeffer 2016). The immigrant population in our case study typically consists of first-generation labour migrants from culturally close countries, who seem to be less associated with neighbourhood conflict as predicted by rational choice theory. In China, however, the number of rural migrants in many cities is very significant indeed even if external immigration remains low. Moreover, the binary nature of the hukou registration system has helped reinforce and entrench social divisions in employment, housing, and social mobility (Chaps. 4, 6, 7, 8, 12 and 15). So there may be much greater potential in the Chinese context for social frontiers to emerge and have significant negative impacts.

Finally, the relatively low level of social inequality in Czechia as compared to countries in Western Europe and the US (Hasman and Novotný 2015) may contribute to a more even spatial distribution of immigrants in the long-run, which may facilitate their integration into the host society by an everyday contact with the out-group, as well as reducing differences across social frontiers, diminishing their impact. So the social frontiers we observed in our study may only represent transient boundaries. However, while the socialist legacy also left low levels of socio-economic inequality in China, the rapid and prolonged pace of economic development there has led to very significant increases in inequality, leaving it with Gini coefficients above most European countries. ${ }^{8}$

Although our findings have identified some conditions which seem to prevent neighbourhood problems occurring near social frontiers, they are not without caveats. First, due to the small number of immigrants holding citizenship of individual countries, we were not able to fully unpack the role of ethnic diversity within the immigrant population and its relationship with crime as suggested by Kubrin et al. (2018). To at least partially overcome this, we used cultural distance to differentiate between two major groups. Second, our approach might be criticised for focusing on (minor)

\footnotetext{
${ }^{8}$ The Gini-coefficient is a widely used measure of income inequality. Its values range between zero and one, with the higher the value, the greater the inequality. The World Bank estimated China Gini-coefficient to be 38.5 in 2016. This compares with estimates of 24.9 for Czechia, 28.8 for Sweden, 31.6 for France, 31.9 for Germany, 34.8 for the United Kingdom, 35.9 for Italy, and 41.4 for the United States (World Bank 2020).
} 
neighbourhood crime while leaving aside serious crimes such as violent and major property crime. However, major crimes are less concentrated in Czechia (Šimon and Jíchová 2020), which suggests that the inconsistent relationship described above would only become weaker when taking major crimes into account. Third, similarly to previous studies in this field (see e.g. Legewie and Schaeffer 2016), our variables are unable to distinguish between intergroup and intragroup conflict. Despite that, they are rather reliable in assessing the ability of communities to maintain order in their local areas.

Bearing in mind these constraints, we believe this study has several merits. First, from a theoretical point of view, it stresses the importance of opening the debate in urban studies to incorporate local findings from beyond the West to achieve a truly international urban theory of social frontiers. Second, our use of cultural distance measures helps to promote a more nuanced approach to studying the impact of segregation and highlights the role of cultural diversity in understanding the link between immigrant segregation and crime. The third merit of this research is empirical, as it brings forward findings from a previously unexplored context, which has important policy implications. In particular, together with Klinger et al. (2017) study, our findings suggest that smaller social stratification (i.e. more social mix) and less segregation in general are related to fewer neighbourhood conflicts. Promoting social equality and social mixing in space thus seems crucial, as it is likely to bring meaningful contact which is believed to contribute to social cohesion. Finally, our chapter does not find evidence that concerns about the negative impacts of immigration, such as increased crime, are empirically grounded in Czechia. However, this may change with the recent rise in xenophobia in the CEE region, largely due to the media reporting on issues with migrant populations in Western European countries and the refugee movements across South-East Europe. One of the worthwhile avenues of future research would be to look at whether and how the nexus between immigration and crime progresses by following these developments. The present study provides the first piece of empirical evidence from the CEE region that can counter the predominantly negative media claims which are seldom evidence-based.

Acknowledgements We are grateful for research grant funding from the UK Economic and Social Research Council (ESRC) 'Understanding Inequalities' project (Grant Reference: ES/P009301/1) and for financial support from the Czech Science Foundation 'Spatial Patterns of Crime and the Perception of Safety in Czechia' (Grant Reference: 16-02242S). We also thank Jana Jíchová for insightful comments to earlier versions of this chapter.

\section{References}

Allport GW (1954) The nature of prejudice. Addison-Wesley, Reading

Andrijasevic R, Sacchetto D (2008) Migrant labor and temporary work agencies in the case of Foxconn in the Czech Republic. Urban People/Lidé Města 16(2):287-298

Bakens J, Pryce G (2018) Homophily horizons and ethnic mover flows among homeowners in Scotland. Housing Stud 34(6):925-945 
Bolt G, van Kempen R, van Ham M (2008) Minority ethnic groups in the Dutch housing market: Spatial segregation, relocation dynamics and housing policy. Urban Stud 45(7):1359-1384

Brantingham P, Brantingham P (1995) Criminality of place. Crime generators and crime attractors. Eur J Crim Policy Res 3(3):5-26

Čermáková D, Leontiyeva Y (2017) 'I do not mind immigrants; it is immigration that bothers me.' The inconsistency of immigration attitudes in Europe. Geografie 122(4):500-525

Cheshire P (2009) Policies for mixed communities: Faith-based displacement activity? Int Reg Sci Rev 32(3):343-375

Clarke RV, Felson M (1993) Introduction: criminology, routine activity, and rational choice. In: Clarke RV, Felson M (eds) Routine activity and rational choice. Transaction Publishers, New Brunswick, London, pp 1-14

Cook J, Dwyer P, Waite L (2011) 'Good relations' among neighbours and workmates? The everyday encounters of accession 8 migrants and established communities in Urban England. Popul Space Place 17(6):727-741

Dean N, Dong G, Piekut A, Pryce G (2018) Frontiers in residential segregation: Understanding neighbourhood boundaries and their impacts. Tijdschrift Voor Economische En Sociale Geografie 110(3):271-288

Dražanová L (2018) Immigration and the Czech presidential election. LSE European Politics and Policy (EUROPP) Blog, https://bit.ly/2U8smJc (accessed 13th May 2020).

Drbohlav D (2012) Patterns of immigration in the Czech Republlic, Hungary and Poland. A comparative perspective. In: Okólski M (ed) European immigrations. Trends, structures and policy implications. Amsterdam University Press, Amsterdam, pp 179-209

Drbohlav D, Valenta O (2014) Czechia: the main immigration country in the V4. In: Eröss Á, Karácsonyi D (eds) Discovering migration between Visegrad countries and Eastern Partners. HAC RCAES Geographical Institute, Budapest, pp 41-71

Engbersen G, van San M, Leerkes A (2006) A room with a view. Irregular migrants in the legal capital of the world. Ethnography 7(2):209-242

Eröss Á, Karácsonyi D (2014) Discovering migration between Visegrad countries and Eastern Partners. HAS RCAES Geographical Institute, Budapest

Fabula S, Boros L, Kovács Z, Horváth D, Pál V (2017) Studentification, diversity and social cohesion in post-socialist Budapest. Hung Geogr Bul 66(2):157-173

Finney N, Simpson L (2009) 'Sleepwalking to segregation': Challenging myths about race and migration. Policy Press, Bristol

Gould RV (2003) Collision of Wills. How ambiguity about social rank breeds conflict. The University of Chicago Press, Chicago, London

Haberman CP, Ratcliffe JH (2015) Testing for temporally differentiated relationships among potentially criminogenic places and census block street robbery counts. Criminology 53(3):457-483

Hasman J, Novotný J (2015) Cross-national variation in income inequality and its determinants: An application of Bayesian model averaging on a new standardized inequality data set. Prague Econ Pap 24(2):211-224

Hlinčíková M, Chudžíková A, Gallová Krieglerová A, Sekulová M (2014) Migranti v meste. Prítomní a (ne)viditeľní [Migrants in the city. Present and (in)visible]. Inštitút pre verejné otázky, Centrum pre výskum etnicity a kultúry, Bratislava

Järv O, Müürisepp K, Ahas R, Derudder B, Witlox F (2015) Ethnic differences in activity spaces as a characteristic of segregation: A study based on mobile phone usage in Tallinn. Estonia. Urban Stud 52(14):2680-2698

Kang S (2016) Inequality and crime revisited: effects of local inequality and economic segregation on crime. J Popul Econ 29(2):593-626

Klinger J, Müller S, Schaeffer M (2017) Der Halo-Effekt in einheimisch-homogenen Nachbarschaften [The Halo-Effect in Homogeneous Neighborhoods]. Zeitschrift Für Soziologie 46(6):402-419 
Kong L, Qian J (2019) Knowledge circulation in urban geography/urban studies, 1990-2010: Testing the discourse of Anglo-American hegemony through publication and citation patterns. Urban Stud 56(1):44-80

Kramer R (2017) Defensible spaces in Philadelphia: Exploring neighborhood boundaries through spatial analysis. RSF: Russell Sage Found J Soc Sci 3(2):81-101

Kubrin CE, Hipp JR, Kim YA (2018) Different than the aum of its parts: Examining the unique impacts of immigrant groups on neighborhood crime rates. J Quant Criminol 34(1):1-36

Lee D, Mitchell R (2013) Locally adaptive spatial smoothing using conditional auto-regressive models. J Roy Stat Soc: Ser C (Appl Stat) 62(4):593-608

Lee D, Minton J, Pryce G (2015) Bayesian inference for the dissimilarity index in the presence of spatial autocorrelation. Spatial Stat 11:81-95

Legewie J (2018) Living on the edge neighborhood boundaries and the spatial dynamics of violent crime. Demography 55(5):1957-1977

Legewie J, Schaeffer M (2016) Contested boundaries: explaining where ethno-racial diversity provokes neighborhood conflict. Am J Sociol 122(1):125-161

Lim M, Metzler R, Bar-Yam Y (2007) Global pattern formation and ethnic/cultural violence. Science 317(5844):1540-1544

Maguire A, French D, O'Reilly D (2016) Residential segregation, dividing walls and mental health: a population-based record linkage study. J Epidemiol Community Health 70(9):845-854

Manley D, Johnston R, Jones K (2018) Decomposing multi-level ethnic segregation in Auckland, New Zealand, 2001-2013: Segregation intensity for multiple groups at multiple scales. Tijdschrift voor Economische en Sociale Geografie. https://doi.org/10.1111/tesg.12314.

Massey DS, Denton NA (1988) The dimensions of residential segregation. Soc Forces 67(2):281315

McPherson M, Smith-Lovin L, Cook JM (2001) Birds of a feather: Homophily in social networks. Ann Rev Sociol 27(1):415-444

Medová L, Drbohlav D (2013) Estimating the size of the irregular migrant population in Prague an alternative approach. Tijdschrift Voor Economische En Sociale Geografie 104(1):75-89

Musil J (2005) City development in Central and Eastern Europe before 1990: Historical context and socialist legacies. In: Hamilton IFE, Dimitrovska K, Pichler-Milanović N (eds) Transformation of cities in central and Eastern Europe: Towards globalization. United Nations University Press, Tokyo, New York, Paris, pp 22-43

Neal S, Bennett K, Cochrane A, Mohan G (2013) Living multiculture: understanding the new spatial and social relations of ethnicity and multiculture in England. Environ Plan C: Gov Policy 31:308-323

Openshaw S (1983) The modifiable areal unit problem. Geo Books, Norfolk

OpenStreetMap contributors (2017) Data from Planet dump, OpenStreetMap database. Accessed July 9 2018. https://planet.osm.org.

Ouředníček M (2016) The relevance of 'Western' theoretical concepts for investigations of the margins of post-socialist cities: the case of Prague. Eurasian Geogr Econ 57(4-5):545-564

Pejchal V (2018) Hate speech regulation in post-communist countries: Migrant crises in the Czech and Slovak Republics. Int J Crime Justice Soc Democracy 7(2):58-74

Phillips D (2010) Minority ethnic segregation, integration and citizenship: A European perspective. J Ethnic Migr Stud 36(2):209-225

Piekut A, Pryce G, van Gent W (2019) Segregation in the twenty first century: Processes, complexities and future directions. Tijdschrift Voor Economische En Sociale Geografie 110(3):225-234

Pratt TC, Cullen FT (2005) Macro-level assessing of crime: A meta-analysis. Crime Justice 32:373450

Přidalová I, Hasman J (2018) Immigrant groups and the local environment: socio spatial differentiation in Czech metropolitan areas. Geografisk Tidsskrift-Danish J Geogr 118(1):72-87

Rupnik J (2016) Surging illiberalism in the east. J Democracy 27(4):77-87 
Šamánek J (2008) Lidé z továrny: integrace cizinců v Pardubicích [People from the factory: integration of foreigners in Pardubice]. Migraceonline.cz, September 30. https://migraceonline.cz/ cz/e-knihovna/lide-z-tovarny-integrace-cizincu-v-pardubicich

Sampson RJ, Groves WB (1989) Community structure and crime: Testing social-disorganization theory. Am J Sociol 94(4):774-802

Šimon M, Jíchová J (2020) Stabilita kriminality v místech: obecný model kriminality českého města města [Stability of crime in places: general model of crime of Czech city]. Sociologický časopis/Czech Soc Rev 56(5):619-638

Šimon M, Kř́̌žzová I, Klsák A (2021) New urban diversity at and after the economic downturn: recent trajectories of ethnic segregation in Central European cities. Manuscript

Smith DM (1996) The socialist city. In: Andrusz G, Harloe M, Szelenyi I (eds) Cities after socialism. Blackwell, Cambridge, pp 70-99

Song J, Andresen MA, Brantingham PL, Spicer V (2017) Crime on the edges: Patterns of crime and land use change. Cartogr Geogr Inf Sci 44(1):51-61

Sýkora L, Čaněk M, Fiedlerová K, Trlifajová L, Matoušek R, Brabcová Š (2015) Metodika prevence rezidenční segregace a podpory integrace cizinců v lokalitách koncentrace zahraničních pracovníků [Methodology for prevention of residential segregation and support for integration of foreigners in areas of concentration of migrant workers]. Univerzita Karlova, Multikulturní centrum Praha, Praha

Welzel C (2013) Freedom rising: Human empowerment and the quest for emancipation. Cambridge University Press, New York

World Bank (2020) Gini Index, World Development Indicators, https://data.worldbank.org/indica tor/SI.POV.GINI?view=map (accessed $13^{\text {th }}$ May 2020).

Yao J, Wong DWS, Bailey N, Minton J (2018) Spatial segregation measures: A methodological review. Tijdschrift voor Economische en Sociale Geografie 110(3):235-250

Zalabáková J (2012) Afričané, Romové a další 'cizinci' v české mediální realitě [Africans, Roma and other 'foreigners' in the Czech media reality]. Antropowebzin 6:79-87

Open Access This chapter is licensed under the terms of the Creative Commons Attribution 4.0 International License (http://creativecommons.org/licenses/by/4.0/), which permits use, sharing, adaptation, distribution and reproduction in any medium or format, as long as you give appropriate credit to the original author(s) and the source, provide a link to the Creative Commons license and indicate if changes were made.

The images or other third party material in this chapter are included in the chapter's Creative Commons license, unless indicated otherwise in a credit line to the material. If material is not included in the chapter's Creative Commons license and your intended use is not permitted by statutory regulation or exceeds the permitted use, you will need to obtain permission directly from the copyright holder.

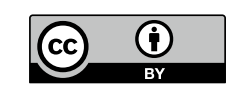

